YEARBOOK

of ANTITRUST

and REGULATORY

STUDIES

www.yars.wz.uw.edu.pl
Peer-reviewed scientific periodical, focusing on legal and economics issues of antitrust and regulation. Creative Commons Attribution-No Derivative Works 3.0 Poland License

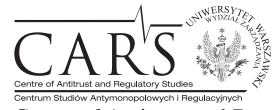

Centre of Antitrust and Regulatory Studies,

University of Warsaw, Faculty of Management www.wZ.uw.edu.pl

\title{
Legislative Developments in Rail Transport in 2009
}

by

\author{
Katarzyna Zawisza*
}

\section{Introduction}

Several major changes were introduced into Polish rail transport law in 2009. As it is often the case with legislative changes of recent years, most of the amendments were inspired by European law. The transposition deadlines for several major directives passed in 2009 accompanied by the entry into force of some key EU regulations in the area of rail transport. The long awaited amendments relating to the liability of railway undertakings and insurance obligations relating to passengers, their luggage and train delays ${ }^{1}$ were finally introduced in 2009 . At the same time, railway undertakings were very concerned with the implementation of Directive 2007/58/EC 2 introducing infrastructure access rights for rail carriers from other Member States in relation to international passenger services.

* Katarzyna Zawisza, Senior Legal Expert at the European Union Law Department of the Ministry of Foreign Affairs. The views expressed are those of the author and do not represent the views, and should not be attributed to the Ministry of Foreign Affairs.

1 These changes are the consequences of Regulation (EC) No. 1371/2007 of the European Parliament and of the Council of 23 October 2007 on rail passengers' rights and obligations, OJ [2007] L 315/14.

2 Directive 2007/58/EC of the European Parliament and of the Council of 23 October 2007 amending Council Directive 91/440/EEC on the development of the Community's railways and Directive 2001/14/EC on the allocation of railway infrastructure capacity and the levying of charges for the use of railway infrastructure, OJ [2007] L 315/44. 


\section{The Act of 25 June 2009 Amending the Act on Rail Transport}

\section{Rail passengers' rights}

The Act of 28 March 2003 on Rail Transport ${ }^{3}$ (in Polish: Prawo Kolejowe, hereafter PK) was amended only once in 2009. However, the Amendment Act of 25 June $2009^{4}$ affected several crucial areas of Polish rail transport law. The Amendment Act of 25 June 2009 included provisions eagerly awaited by millions of passengers establishing the responsibility of railway operators for rail schedule delays. Formally speaking, these obligations result from the directly applicable Regulation (EC) 1371/2007 on rail passengers' rights and obligations. The Amendment Act ensured however that the President of the Rail Transport Office (in Polish: Urzad Transportu Kolejowego, hereafter UTK) would have control over their fulfillment. Such institutional oversight was both necessary and required in order to enforce Regulation 1371/2007. The provisions on control over the fulfilment of obligations deriving from the EU act are now contained in Article 14a(3) PK - it is exercised by the UTK President, among other things, by means of decisions issued according to Article 14a(4) PK. UTK decisions concerning the behaviour of entities subjected to obligations imposed by the Regulation may impose a duty to remove the infringement. As they are issued in the form of administrative decisions, their addressees have the right to file a motion for the re-consideration of the case by UTK and subsequently, to file a complaint against a renewed decision to an administrative court. In order to enable the regulator to ensure the enforcement of Regulation 1371/2007, the amended Article 15(1) PK entitles the UTK President, and those he/she so authorises, to enter side-tracks, railway zones, rooms connected with railway traffic management and railway vehicles including a right to travel by a train or a railway vehicle. The UTK President was also made responsible for the assessment of passenger complaints concerning infringements of the provisions of this EU Regulation. These complaints are settled by way of an administrative decision which may affirm an infringement (defining its scope and the removal deadline) or state its absence (Article 14a(6)). The newly added Article 47(8) PK requires additionally that railway undertakings take up an insurance cover that extends also over their liability under Regulation 1371/2007 as required by its Article 12. Finally, the newly added Article 66(1) point 4 PK allows the UTK President to impose a fine on anyone subject to the aforementioned obligations if they were to fail to fulfil them.

\footnotetext{
3 Consolidated text: Journal of Laws 2007 No. 16, item 94, as amended.

${ }^{4}$ Journal of Laws 2009 No. 214, item 1658.
} 
It is crucial to stress here however that Poland has used the possibility to introduce exemption periods resulting from Article 2(4-6) of Regulation 1371/2007. The Regulation states that Article 9 (Availability of tickets, through tickets and reservations), Article 11 (Liability for passengers and luggage, not including Chapter II of Annex I introducing liability in cases of failures to keep to the timetable), Article 12 (Insurance), Article 19 (Right to transport), Article 20(1) (Information to disabled persons and those with reduced mobility) and Article 26 (Personal security of passengers) shall apply to all rail passenger services throughout the EU from the moment of the entry into force of this Regulation. Article 3a PK added by the Act of 25 June 2009 introduced however into Polish law the exemption contained in Article 2(5) of the Regulation that concerns the application of some of its provisions to urban, suburban and regional rail passenger services. The amending act introduced also the exemption permitted by Article 2(4 and 6) of the Regulation whereby the application of some of its provisions is excluded in domestic rail passenger services and in relation to rail passenger services provided by connections including stations outside the European Union. This latter exemption was granted for the period of around one and a half year starting from the entrance into force of Regulation 1371/2007.

At the same time, the Amendment Act introduced a procedure for the renewal of the two aforementioned types of exemptions (i.e. domestic rail passenger services and connections with stations outside the European Union). A general exemption for all such services is granted until 30 June 2011. Afterwards, it may be granted on request of an interested entity by the Minister of Infrastructure for a maximum period of 5 years after the entry into force of Regulation 1371/2007 - until 3 December 2014. It may then be prolonged twice for a maximum period of five years each, as permitted by the Regulation. Renewal applications should be submitted by 31 May 2014 and 31 May 2019 respectively. The Amendment Act equally allows those operators that will enter the market after 31 May 2014 or 31 May 2019 to file a motion for each of the two exemption periods. Requests submitted to the Ministry of Transport should specify the scope of the requested exemption and the timetable of the adjustment to the Regulation.

The above notwithstanding, Poland has decided that some of the provisions of Regulation 1371/2007, from which the aforementioned services could be exempt, will in fact apply to these types of rail passenger transport. These provisions concern: Article 4 (conclusion and performance of transport contracts, the provision of information and tickets), Article 5 (enabling passengers to bring bicycles on to the train), Article 8(1) (travel information), Article 16 (reimbursement and re-routing in case of expected delays longer than 60 minutes in the arrival at the final destination), Article 21(2) and 
Articles 22 - 24 (access to transport and assistance for disabled persons and those with reduced mobility), Article 27 (passenger complaints), Article 29 (information to passengers about their rights), Article 28 (service quality standards and quality management system).

It is worth noting that these exemptions had to be introduced first by way of a Communication of the Ministry of Infrastructure issued on 25 November 2009 on the non-application of some of the provisions of EU law concerning rail passengers' rights and obligations ${ }^{5}$ before the Amendment Act of 25 July actually entered into force. This solution was caused by a motion filed with the Constitutional Tribunal by the Polish President as to the compatibility of the Amending Act with the Polish Constitution. Questioned were, among others, some of its provisions connected with Regulation No 1371/2007. The President asked the Tribunal to examine whether Article 14a(2) PK, added by the Amending Act of 25 July, did not actually infringe the principle of the definiteness of the law. It also concerned the opening of the market for rail passenger services, namely the compatibility of Article 29a(1) PK with the rule of equal treatment and non-discrimination contained in Article 32 of the Constitution. The motion was settled by the Tribunal exactly on the date of the entry into force of Regulation 1371/2007. The Constitutional Tribunal ruled $^{6}$ that the abovementioned provisions are in compliance with the Polish Constitutional Act.

\section{Certification of train drivers operating locomotives and trains}

The Amending Act of 25 June 2009 transposed also Directive 2007/59/EC on the certification of train drivers operating locomotives and trains on the railway system in the Community ${ }^{7}$. However, full implementation will only be ensured after the issuance of additional acts of secondary legislation. The Directive introduced two types of documents required for drivers operating locomotives and trains in the EU: licences and certificates. In line with the Directive, the Amending Act has excluded metro drivers from this licensing and certification system. According to new wording of Article $22 \mathrm{PK}$, the

5 Komunikat Ministra Infrastruktury z dnia 25 listopada 2009 r. w sprawie niestosowania niektórych przepisów Unii Europejskiej dotyczących praw i obowiązków pasażerów w ruchu kolejowym [Communication of the Minister of Infrastructure of 25 November 2009 on nonapplication of some EU provisions regarding rights and duties of passengers in rail transport], Journal of Laws 2009 No. 77, item 961.

6 Judgment of the Constitutional Tribunal of 3 December 2009, KP 8/09, Journal of Laws 2009 No. 78, item 985.

7 OJ [2007] L 315/51. 
UTK President issues, prolongs, suspends and withdraws such licences. The regulatory authority updates also the related data and issues duplicates. The Directive specifies the minimum conditions to be fulfilled by a candidate as regards medical requirements, basic education and general professional skills. A driver who acquired a licence may apply for a certificate. Certificates are issued by railway operators and infrastructure managers. The procedures of issuing certificates are regulated by railway operators and railway managers (Article 22b PK). One driver may hold one or more certificates. Each of them shall indicate both the rolling stock which the holder is authorised to drive and the infrastructures on which he/she is authorised to drive. The UTK President runs a license record, a list of entities entitled to train and examine the applicants for licenses and certificates and a list of entities authorized to conduct medical examinations required for obtaining and ensuring the validity of licenses or certificates. Article 22c PK includes now special rules on training costs incurred by an operator or infrastructure manager in cases where the employment contract, or of any other form of cooperation, is dissolved pre-term on the account of the driver. This provision implements Article 24 of the Directive, which obliges Member States to 'ensure that the necessary measures are taken in order to ensure that investments made by a railway undertaking or an infrastructure manager for the training of a driver do not unduly benefit another railway undertaking or infrastructure manager in the case where that driver voluntarily leaves the former for the latter railway undertaking or infrastructure manager'. Taking into account how high the training costs for train and locomotive drivers are, this rule may be of a significant importance.

The provisions concerning train drivers and the system of their licensing and certification shall enter into force on 4 December 2010 that being the transposition deadline for Directive 2007/59/EC. Finally, the Amendment Act limits the validity of licensing documents issued on the basis of previous provisions until 1 January 2017 and thus, from that moment on, drivers will be obliged to have new licences and certificates issued in line with Directive 2007/59/EC.

\section{Right of access to infrastructure for EU/EFTA railway operators providing international passenger services}

The second most awaited amendment of rail transport law in 2009 was the further opening of railway services, this time, with respect to international passenger travel. The amendment was forced by Directive 2007/58/EC of the European Parliament and of the Council of 23 October 2007 amending Council 
Directive 91/440/EEC on the development of the Community's railways and Directive 2001/14/EC on the allocation of railway infrastructure capacity and the levying of charges for the use of railway infrastructure. The Directive was enacted as a reaction to the difficulties experienced by long-distance rail services in Europe and the competitive pressure of low-cost airlines. Its transposition consisted of the introduction of provisions on the right of access to infrastructure for rail carriers from other Member States operating in the international passenger services field.

The amended Article 29a(1) PK contains now the right of access to infrastructure in order to provide international passenger services by railway undertakings established in other Member States of the EU and Member States of EFTA - parties to the EEA Agreement. It concerns undertakings authorized to provide rail transport services according to the law of the Member State of their establishment ${ }^{8}$. The previous wording of Article 29(1) PK acknowledged their right of access only with respect to international goods transport. Article 29 (4-11) were added by the Amendment Act of 25 July 2009. They set out a procedure for operators established in other Member States providing international rail passenger services to apply for the allocation of railway lines in Poland. These applications are necessary to enable an infrastructure manager to plan its railway timetable ${ }^{9}$. The application is to be filed at latest six months before the day when a new timetable is to be introduced. The Polish railway timetable is fixed once a year; it changes at midnight on the second Saturday of December; it may also be exceptionally changed at midnight on the second Saturday of June in particular because of changes in regional timetables of passenger trains (Article $30 \mathrm{PK}$ ).

The UTK President was charged with ensuring equal infrastructure access for those railway operators who provide international passenger services including those established in other EU/EFTA Member States (Article 13(2)(2) PK).

The right of access to a railway line may be limited on request of an operator or a competent authority fulfilling a public service contract. This limitation may be based on two reasons. First, a limitation may be justified if most services provided by the applicant are to be provided within the Polish territory.

8 This results from the fact that Council Directive of 29 July 1991 on the development of the Community's railways (91/440/EEC) applies to the management of railway infrastructure and to rail transport activities of the railway undertakings established or to be established in a Member State (Article 2(1). According to Article 4(1) of Directive 91/440/EEC, a railway undertaking shall be entitled to apply for a licence in the Member State in which it is established.

9 Article $30 \mathrm{PK}$ regulates the procedure for the composition of the rail timetable; it contains special provisions concerning rail passenger services introduced by the Amendment Act of 6 December 2008 - adding paragraphs 2 a) - 2 c) to this Article, which aims to adjust the timetable to better answer the needs of passengers. 
Second, a limitation may be justified by the fact that a planned connection would injure the economic equilibrium of services which are provided on the basis of public service contracts (the motion for such examination may also be filed by an infrastructure manager). The possibilities of access limitation result from Article 10(3a -3b) Directive 91/440/EEC (added by Directive $2007 / 58 / E C)$. If it is established that a connection would threaten the economic equilibrium of public services, the limitation may concern the stations at which an operator plans its train stops or the frequency of services (compatible with Article 10(3b) Directive 91/440/EWG). Its addressees may file a motion for the reconsideration of its case and than a complaint to an administrative court against a renewed decision.

The details of the access granting procedure to railway undertakings established in other Member States are contained in the Regulation of the Minister of Infrastructure of 30 December 2009 on Access to Railway Infrastructure for Railway Operators Established in Another Member State of the EU or Member State of EFTA - Party to the EEA Agreement ${ }^{10}$. Paragraph 2 of the Regulation specifies what information must be provided to the UTK President and the infrastructure manage by an external operator 90 days before filing an application for the allocation of lines. For the timetable 2009/2010, the Amending Act of 25 July 2009 set this time limit for 2 months starting from the entry into force of this act (it entered into force 14 days after its publication that took place on 16 December 2009). Information provided by an applicant shall include: proposed the train route and stations on this route - both within and outside of Poland; a draft timetable; methods of ticket distribution; a draft tariff offer; predicted number of passengers differentiating the number of passengers transported within the Polish territory; predicted number of passengers getting on and off at each station in Poland; predicted income, indicating income expected from the services provided within the Polish territory; numbers and types of seats offered and train's commercial speed. As annexes to the application, the Regulation requires a declaration on the fulfilment of specified technical requirements and attested copies of license and safety certificate issued for the operator by competent authorities. Information contained in the application is delivered to the authorities awarding public service contracts on this route and to railway operators using it (as required by Article 13(4) added to Directive 2001/14/EC by Directive 2007/58/EC).

Paragraph 3 of the Regulation lists what type of information must be provided in a request for checking the principal purpose of a service and for examining the economic equilibrium of a public service contract. The list is similar to that contained in the application for rail routes. It additionally covers: the timetable

10 Journal of Laws 2010 No. 2, item 7. 
and tariffs on the line concerned; predicted income from the public service and its predicted decrease by the services of the applicant as well as; the number of passengers getting on and off at stations where the applicant plans its train stops. The UTK President should also receive an excerpt of the public service contract. Last important issue that is regulated in paragraph 4 of the Regulation, are the evaluation criteria to be used by the UTK President. The first group contains criteria of assessing the international character of the service: proportion of the train route, number of stops and income (all these elements should show the difference between passenger transport within and outside of Poland) and the number of trains running within a 24 hour slot. The second group lists criteria of appraisal whether the connection would infringe the economic equilibrium of public service contracts. The latter include not only tariffs, predicted incomes on the route within Poland, planned number of stops within and outside of Poland, numbers and categories of seats, train's commercial speed, timetable including the times of stops and trains frequency, but also profitability of the public service concerned and the amount of compensation paid by the authority that awarded the public service contract.

It is hard to evaluate the effects of the opening of rail passenger transport. It is to be expected that the entrance of foreign operators will occur gradually primarily due to high entry costs. Press releases of January 2010 stated that no EU/EFTA railway operator was using this right at that time but that the German operator DB Bahn has indeed filed an access request ${ }^{11}$. At the same time, starting with the timetable for 2009/2010, passenger connections were reorganized and many cancelled. In May 2007, the UTK President launched clarification proceedings to check the functioning of the right of access for railway passenger transport during the use of the 2009/2010 timetable in order to ensure the proper functioning of the railway transport market ${ }^{12}$. An explanatory proceeding was also launched by the President of the Polish Office for Competition and Consumer Protection (in Polish: Urzad Ochrony Konkurencji i Konsumentów, hereafter UOKiK) in order to check the realisation of passenger carriages, the provision of infrastructure access by their managers

11 'Deutsche Bahn: jesteśmy zainteresowani przewozami pasażerskimi w Polsce' ['Deutsche Bahn: We are interested in passenger rail transport in Poland'] (source PAP), 5 January 2010, available at http://logistyka.wnp.pl/deutsche-bahn-jestesmy-zainteresowani-przewozamipasazerskimi-w-polsce,98241_1_0_0.html.

'W 2010 roku kolej w Polsce czeka trzęsienie ziemi - zapowiada Dziennik Gazeta Prawna' ['In 2010 railways in Poland will experience sort of earthquake'] (source: Dziennik Gazeta Prawna), 5 January 2010, available at http://logistyka.wnp.pl/polscy-pasazerowie-pojadaniemiecka-koleja,98151_1_0_0.html.

12 'UTK wszczął postępowanie ws. dostępu do infrastruktury' ['UTK initiated a proceeding on an access to rail infrastructure'] Rynek Kolejowy. Prawo i Polityka, 7 May 2010, available at http://www.rynek-kolejowy.pl/szukaj\&kategoria $=3 \% 7 \mathrm{Cstrona}=1$. 
and potential violations of consumer rights connected with the lack of accurate information on cancelled and changed railway connections ${ }^{13}$.

\section{Duration of framework agreements}

Changes resulting from Directive 2007/58/EC (as it amended Directive 2001/14/EC) concerned also the duration of framework agreements between railway operators and infrastructure managers on the basis of which the former use the allocated routes. According to Article 31(2-4a) PK, these agreements will be now concluded, on principle, for a period of maximum five years with possible renewals. In exceptional circumstances, justified by necessary investments, framework agreements might be concluded for a duration of 15 years or longer. These two possibilities should facilitate investments in specialized infrastructure.

The provisions on access granted to passenger railway operators from other Member States and on the duration of framework agreements entered into force on 1 January 2010, as required by respective provisions of Directive 2007/58/EC.

\section{Licensing of undertakings providing railway transport of passengers or goods or in traction services}

The railway market was also affected by the Regulation of the Minister of Infrastructure issued on 5 June 2009 on the Procedure of Submission and Appraisal of Applications for Licenses which Authorize an Undertaking to Perform the Economic Activity that Consists of the Provision of Railway Transport of Passengers or Goods or Providing Traction Services and on License Patterns ${ }^{14}$. This Regulation implements the pre-accession Council Directive 95/18/EC of 19 June 1995 on the licensing of railway undertakings ${ }^{15}$. According to the new act, applications may be filed either by post or directly at UTK headquarters. In cases of unfinished or incorrect documentation, the applicant is summoned by the UTK President to complete it. After the examination, the procedure finishes with a decision of the UTK President

13 UOKiK Press Release of 6 May 2010: http://uokik.gov.pl//aktualnosci.php?news_ id $=2015 \&$ news_page $=2$.

14 Journal of Laws 2009 No. 94, item 775. The Act was analyzed by the author in: 'Legislative Developments in Rail Transport in 2008' (2009) 2(2) YARS with respect to scarcity charges.

15 Official Journal L 143, 27.6.1995, p. 70. 
granting or refusing to grant a license. The Regulation contains two license patterns. The first authorizes an undertaking to perform the economic activity of providing rail transport of passengers or goods (Annex 1) while the other authorizes an undertaking to perform the economic activity of providing traction services (Annex 2). Both license patterns include information on the holder, on the type of license and its validity as well as on the conditions of its use.

\section{Access to infrastructure and scarcity charges}

The Minister of Infrastructure issued also a new Regulation on 27 February 2009 concerning the Conditions for Access to and the Use of Railway Infrastructure ${ }^{16}$ that repealed the previous Regulation of the Minister of Transport on the Conditions for Access to and the Use of Railway Infrastructure of 30 May $2006^{17}$. The changes introduced by the new act were a continuation of the amendments made by the Act of 24 October 2008 Amending the Act on the Commercialization, Restructuring and Privatization of the State Company 'Polish State Railways' and the Act on Rail Transport ${ }^{18}$. The new Regulation was intended, among other things, to ensure full compliance in this respect with Directive 2001/14/EC. It also introduced many editorial changes improving the comprehensibility of the act.

Rules on congested infrastructure were among the key changes from the point of view of market regulation. Previously, when the capacity of a line or its fragment was insufficient to satisfy the requests of all operators, the infrastructure manager negotiated the price with interested operators until the capacity and the demand for transport in a given time period were balanced (the manager had to consider the rules on route allocation with the priority of passenger services and public service obligations, the allocation of routes which were used by the same operator in the preceding timetable and framework agreements, regulated in paragraph 3(13) of the previous regulation). According to paragraph 3(8) of the new Regulation, unallocated capacity will now have to be put on auction by the infrastructure manager under the supervision of the UTK President. The auction will lead to the establishment of the level of the basic charge increase for this infrastructure. On the basis of paragraph 19(3) of the Regulation, the manager is obliged to publish every year a regulation specifying the procedure to be followed in

\footnotetext{
16 Journal of Laws 2009 No. 35, item 274.

17 Journal of Laws 2006 No. 107 item 737, as amended.

18 Journal of Laws 2008 No. 206, item 1289.
} 
case of an auction concerning congested infrastructure. Unlike the earlier solution, the new procedure should no longer raise doubts from the point of view of Article 30(3) Directive 2001/14/EC seeing as it provides for direct supervision of the procedure by UTK President. Indeed, Article 30(3) of the Directive allows negotiations between applicants and an infrastructure manager on the level of infrastructure charges only under the supervision of an appropriate regulatory body, requiring it to intervene if negotiations are likely to contravene the Directive.

The new Regulation shortens the time in which the manager should draw up a draft timetable and deliver it to the operator for consultation; the operator is now obliged to do this not later than three months after the expiration of the deadline for the submission of applications for route allocation. An operator is entitled to submit observations and to propose changes to the draft if it does not satisfy its requests. After receiving such observations and proposals, the manager should inform the operator within seven days if it is unable to make the proposed changes. In this case, the manager shall consult with the operator within fourteen days from receiving the proposed changes. On the basis of such draft, the manager formulates a binding timetable and delivers it to the operator in the form of a notification of the allocated routes. This notification constitutes a confirmation for the reservation of access to the infrastructure required (all this procedure is described in paragraph 4 of the Regulation). Paragraph 5 enumerates the reasons that may justify a refusal of route allocation by the manager.

Paragraphs 6-18 of the new Regulation concern charges. Many provisions have undergone editorial changes; in general, the new act is clearer and more accurate than the previous one; for instance, paragraph 6 specifies now in more detail what elements are taken into account while establishing the rate of the basic charge for a given category of railway lines. The new regulation unifies the charges and makes the system simpler and more comprehensible overall. It reduces the number of train categories which are subjected to different rates of the basic charge - four categories (paragraph 8(1) of the previous regulation) were reduced up to only two categories, namely passenger and goods trains.

The Regulation eliminated separate rates for trains in intermodal transport and for separated railway vehicles. This eliminated situations when a railway operator, irrespective of whether it uses intermodal carriages or not, co-finances such carriages and bears the costs generated by other market participants. This situation was caused by the fact that the older provisions had established lower rates for intermodal carriages, what created benefits for those operators who provided such services (intermodal carriages). Moreover, the elimination of a lower rate for separated railway vehicles should encourage operators to 
eliminate unnecessary runs of such vehicles. It will also cut out the paradox when the operators that less often used separated railway vehicles had been financing the costs created by those operators that used such vehicles more frequently.

The costs taken into account for the calculation of rates are also defined in more details now. Paragraph 8(1) of the Regulation issued on 27 February 2009 states that rates are calculated for the infrastructure access to which is been planned. Furthermore, paragraph 8 point 3 clearly stipulates that rates for lines of the same category and the same total gross weight should be identical. The rules on discounts have also been changed. The previous provision (paragraph 10(2) of the old regulation) stated that the discount, meant to increase the use of lines with a high level of untapped capacity, could not have been higher than: the sum of variable costs, costs of credit-service maintenance as well as maintenance and repair costs sued for the calculation of the rate. The new paragraph 9 point 2 limits the discount to that part of the charge which results from indirect costs only that include costs related to contracts regulating access to infrastructure - these may be e.g. costs of management, costs of ensuring safe and hygienic work, property insurance, costs of the supervision of construction etc. As a result, the qualification of costs as indirect should be made on a case by case basis. The new Regulation no longer differentiates between constant and variable costs. Its paragraph 10 introduced a sharp limitation for the minimum rate of the basic charge - it may not be lower than $75 \%$ of the rate for a given category of railway lines and the total gross weight of a train. Paragraph 18 point 2 of the Regulation clearly states that in cases where an operator resigns from the run of a train at least 30 days before its planned date, the manager will not collect reservation charges. Moreover, point 1 of paragraph 18 specifies that the reservation charge is calculated separately for each route that has been reserved.

The new Regulation does not allow the manager to apply indicators (defined by the manager himself) that decrease the rates of the basic charge and correspond to the decreased costs in some situations. Previously, it happened e.g. when an operator applied for the allocation of a significant percentage of the capacity or when it was the only operator providing carriages on a given line. Even if the possibility to decrease the rates in this way was limited to situations when the decreasing indicators concerned equally all the operators, the change in this scope should improve the clarity and competitiveness. On the contrary, the regulation upholds some of the situations when the manager may apply the indicators increasing the rates.

The new act obliges also the manager to deliver to the UTK President (nine months before the introduction of a new timetable, it used to be eleven months) draft rates of scarcity charges (for both basic charge and charges 
for additional services) together with the list of managed railway lines, rates for passenger and goods trains on these lines with the indicators increasing them and the rules on discounts. An operator is also entitled to demand the presentation of the draft and of the aforementioned list [paragraph 16(1-3)]. This should guarantee greater procedural transparency.

The rates of the charges as well as their increases and discounts should be calculated so as to ensure protection against unjustified increase of the previous and the actual level of the rates [paragraph 16(4)]. Thus, the UTK President should ensure that a manager does not make use of its monopolistic position and does not collect excessive charges (paragraph 17 point 1 together with paragraph 16(4) of the draft) in the course of the procedure that finishes with the acceptance of the rates. When doubts arise as to the increase of the rates established by an operator, the UTK President may consult with auditors or independent experts.

Despite all these changes meant to ensure full compliance with Directive 2001/14/EC, the European Commission decided in June 2010 to refer Poland (among thirteen other MS) to the Court of Justice for failing to correctly implement Directives 91/440/EEC, as amended, and Directive 2001/14/EC 19 .

It can be concluded on the basis of the above analysis that the recent changes in Polish rail transport law are surely going towards an increase in competition and competitiveness. The important and strenuous goal of restructuring and modernizing Polish railways clearly remains. The year 2010 is full of plans to restructure the PKP holding and in particular, ensuring full legal and functional independence of PKP PLK (the main infrastructure manager in Poland) from railway operators. There are also drafts of laws intended to enable railway companies to be declared insolvent. Time will show whether EU legislation and the constant vigilance of the European Commission, will manage to speed up this process. Important EU directive are to be transposed into the Polish legal systems in 2010 including, for instance, Directive 2008/57/ EC of the European Parliament and of the Council of 17 June 2008 on the interoperability of the rail system within the Community ${ }^{20}$.

19 EUROPA Press Release IP/10/807 of 24 June 2010: Rail services: 'Commission legal action against 13 Member States for failing to fully implement first railway package', available at http://europa.eu/rapid/pressReleasesAction.do? reference $=\mathrm{IP} / 10 / 807 \&$ format $=$ HTML\&aged $=0$ \&language $=\mathrm{EN} \&$ guiLanguage $=$ en

20 OJ [2008] L 191/1. 